\title{
Правове забезпечення публічних та приватних інтересів у фауністичному праві України в контексті права власності на тваринний світ
}

У статті досліджуються основні питання права власності на тваринний світ і його об'єкти через призму публічної і приватної власності. Встановлено, що тваринний світ є унікальним природним ресурсом, а видові, фізіологічні та біологічні особливості тварин обумовлюють міждисциплінарний характер правової регламентації суспільних відносин в сфері власності на твариний світ. Розмежування сфер впливу громадянського (приватного) і екологічного (публічного) права має важливе як теоретичне, так і практичне значення для забезпечення реалізації відповідних інтересів учасників суспільних відносин. На підставі узагальнення наукової доктрини, автор підтримує існуючі напрацювання та обгрунтовує необхідність оптимального збалансування цих інтересів, а в разі виникнення конфлікту інтересів пропонує пріоритетом визнвати публічні інтереси, які спрямовані на раціональне використання об'єктів тваринного світу, збереження популяцій диких тварин і місць їх проживання зокрема, і забезпечення сприятливої екологічної обстановки в світі у цілому. Безпосереднє апелювання до фауністичного законодавства доводить існування подвійної юридичної конструкції права власності: з одного боку, власником всього тваринного світу як об'єкту права власності $є$ Український народ як інтегруюча правова категорія, а 3 іншого боку, конкретні індивідуалізовані об'єкти тваринного світу можуть перебувати й у державній, комунальній або приватній власності. Особливості змісту права власності щодо володіння, користування та розпорядження об'єктами тваринного світу грунтуються на екстраполяції норм двох галузей права, що обумовлює співвідношення еколого-правових та цивільно-правових підстав виникнення, зміни та припинення права власності на тваринний світ. Такий міжгалузевий підхід до правового регулювання відносин приналежності на зазначений об'єкт охорони навколишнього природного середовища вимагає дотримання публічних та приватних інтересів, що, у свою чергу, може забезпечуватися імплементацією екологічного імперативу у приватне право.

Ключові слова: право власності на тваринний світ, публічна власність, приватна власність, публічно-приватні засади права власності на тваринний світ, екологічні інтереси.

Постановка наукової проблеми та її значення. Еволюційний розвиток соціальноекономічних відносин суспільства та держави створив підгрунтя для концептуального перегляду парадигми побудови взаємозв'язків між політико-правовими утвореннями та індивідуальними суб' єктами права 3 переходом на приватноправові засади розподілу матеріальних благ. Поява та інтенсивне поширення нової форми власності, безумовно, потребувало наукового обгрунтування, визначення співвідношення та узгодження змісту права приватної та існуючої на той час виключної державної власності (публічної).

Аналіз наукових досліджень цієї проблеми. Загальнотеоретичною основою наукового дослідження правового забезпечення публічно-приватних засад у фауністичному праві в контексті права власності на тваринний світ стали наукові напрацювання таких вчених у галузі екологічного права, як Г. В. Анісімова, А. П. Гетьман, І. І. Каракаш, Н. Р. Кобецька, П. Ф. Кулинич, В. В. Петров, А. К. Соколова, П. В. Тихий, В. С. Шахов та ін. Крім того, враховуючи специфіку теми дослідження та міждисциплінарний характер поняття права власності, у роботі використані праці представників цивільно-правової науки, а саме М. В. Домашенко, Е. В. Мичурина, І. В. Спасибо-Фатєєвої, В. А. Устименко, які присвятили свої праці з'ясуванню сутності, форм, принципів та механізму й гарантії реалізації права власності. Водночас, на доктринальному рівні відсутне комплексне теоретико-правове дослідження забезпечення й реалізації публічно-приватних засад у процесі регламентування відносин щодо приналежності (власності) на об'єкти тваринного світу.

Формулювання мети та завдань статті. Мета наукової роботи полягає у грунтовному науково-теоретичному аналізі правових засад забезпечення публічних й приватних інтересів на підставі дослідження сутності та критеріїв розмежування публічної і приватної власності в аспекті приналежності тваринного світу. 
Виклад основного матеріалу й обгрунтування отриманих результатів дослідження. Сучасні соціально-економічні умови, орієнтовані на прогресивний розвиток та посилення правового статусу конкретних суб'єктів приватного права, забезпечення їх прав та законних інтересів, й водночас, суспільна необхідність у забезпеченні сприятливої екологічної ситуації та екологічної безпеки, раціонального використання природних ресурсів обумовлюють концептуальний перегляд традиційної ідеології щодо системи національного права. Зазначені фактори не повинні реалізовуватися ізольовано один від одного, а навпаки, їх оптимальне співвідношення у практичній площині стане виваженим кроком у подоланні довготривалого антагонізму між правом приватним та публічним.

Варто відзначити, що модернізація принципу розподілу матеріальних благ у суспільстві та новий курс державної економіки, орієнтований на перехід до ринкових форм господарювання вимагав адекватної правової регламентації соціально-економічних перетворень. В той же час, для приведення у відповідність чинного на той час законодавства до нових політико-правових та економічних реалій відбувалося безсистемно та непослідовно, що врешті обумовило існування явища еклектизму у правовій системі, неузгодженості та наявності колізій між нормами різних галузей права. Вже звичним для сучасної правової дійсності та практики правозастосування є ситуації, коли правовий режим одного й того самого об'єкту визначається декількома галузями права по-різному, створюючи при цьому істотні суперечності або ж взагалі прогалини. Наочним прикладом зазначеного $\epsilon$ право власності на тваринний світ, поняття, зміст, умови та інші особливості якого визначаються як екологічним, так і цивільним правом. Відтак, суттєве значення має розмежування цих галузей в аспекті визначення особливостей приналежності тваринного світу, оскільки в екологічному праві превалюють публічно-правові норми, а цивільне право розглядається як право приватне.

За справедливим зауваженням I. I. Каракаша сьогодні, поєднання ринкових механізмів і державного управління в структурі «змішаної економіки» грунтується на комбінуванні державної та приватної власності на засадах державно-приватного партнерства, тенденції розвитку якого визначені

у сучасному українському законодавстві. Відносини державно-приватного партнерства характеризуються поширенням та реальним функціонуванням як приватноправової, так і публічноправової форм власності, а також формуванням на договірних засадах спільної власності на існуючі, зокрема, відтворювані об'єкти шляхом реконструкції, модернізації і технічного переоснащення [1, c. 387].

Вважаємо, що правовий режим тваринного світу в контексті закріплення його приналежності й особливостей реалізації права власності на нього, концептуально обумовлюється функціями в системі суспільних відносин. За аналогією проведеного П. Ф. Кулиничем компаративістського дослідження специфіки права власності на землю крізь призму виконуваних нею функцій [2, с. 295], слід підкреслити, що тваринний світ може виступати у правовідносинах у декількох якостях: як природний ресурс, джерело духовного та естетичного збагачення і виховання людей, об'єкт наукових досліджень, важлива база для одержання промислової і лікарської сировини, харчових продуктів та інших матеріальних цінностей [3]. Перші три аксіологічні ролі, які виконують тварини орієнтовані на забезпечення публічного екологічного інтересу, зміст якого зводиться до забезпечення гармонійного співіснування людини та навколишнього природного середовища, збереження безпечного для життя людини та живої природи й функціонування неживої природи, довкілля. Якщо ж об'єкти тваринного світу розглядаються виключно через економічний контекст як сировина, що використовується у харчовому та промисловому виробництві, то такі відносини набувають приватноправового характеру.

Безпосереднє апелювання до фауністичного законодавства доводить існування подвійної юридичної конструкції права власності: з одного боку, власником всього тваринного світу як об'єкту права власності є Український народ як інтегруюча правова категорія, а з іншого боку, конкретні індивідуалізовані об’єкти тваринного світу можуть перебувати й у державній, комунальній або приватній власності.

Зазначена законодавча архітектоніка відносин власності на тваринний світ, на наше переконання, по-перше, дозволить досягти основної мети оголошення природних ресурсів об' єктом права власності Українського народу - формування соціально-економічної бази існування держави, реалізація концепції суспільної власності, що зобов'язує створення нормативних засад для обмеження абсолютного характеру права власності щодо об'єктів тваринного світу, його «соціалізація»; подруге, сприятиме реалізації одного із основних принципів права власності на природні об' єкти, який забезпечує державні гарантії щодо рівного доступу до них, забезпечення їх сталого використання тощо - відсутність безхазяйних природних об'єктів [4, с. 47]. 
В юридичній літературі відображені різні погляди на співвідношення публічної та приватної форм власності, а також критеріїв їх розмежування. Так, у цивілістичній доктрині формується думка, що приватна власність $є$ антагонізмом публічній власності. При цьому державна власність $є$ ні чим іншим як «приватна власність держави», оскільки значним масивом того, чим володіє держава, може володіти й звичайний власник - суб'єкт приватного права [5, с. 111]. А тому в майбутньому уявлення про право приватної власності охоплюватиме право власності будь-яких суб'єктів, в тому числі держави й територіальних громад. Під публічною же власністю розумітиметься дещо, що протистоїть власності приватній й ії̈ суб'єктом має бути указаний в Конституції Український народ [5, с. 112].

Безумовно, що оптимальною моделлю модернізації фауністичних правовідносин має бути адекватне збалансування публічно-правових та приватних засад розвитку міждисциплінарного інституту права власності на тваринний світ. Такий концепт грунтується на одному із основоположних принципів охорони навколишнього природного середовища - науково обгрунтоване узгодження екологічних, економічних та соціальних інтересів суспільства на основі поєднання міждисциплінарних знань екологічних, соціальних, природничих і технічних наук та прогнозування стану навколишнього природного середовища (ст. 3 Закону України «Про охорону навколишнього природного середовища» [6]. Однак, у випадку конкуренції економічних та природоохоронних функцій тваринного світу, суперечностей цивільного та екологічного права, повинні превалювати публічні інтереси, вираження та закріплення яких втілюється у нормах екологічного права. Декларування примату публічної власності над приватною випливає й із Резолюції 1803 (XVII) Генеральної Асамблеї ООН «Невід’ємний суверенітет над природними ресурсами» від 14.12.1962 p. [7].

Не менш важливим питанням в контексті розмежування публічної та приватної власності є концептуалізація критеріїв уніфікації й диференціації зазначених форм власності. При вирішенні цієї складної дилеми останнім часом науковці апелюють до категорії інтересу [8, с. 47; 9, с. 547; 10; 11$]$. Так, наприклад, М.В.Домашенко вважає, що публічний чи приватний інтерес задовольняється передусім при реалізації повноважень власника й акцентує, що зміст права власності не належить до розмежувальних ознак, оскільки для двох форм права власності він є однаковим [11, с. 546].

Співвідношення приватного та публічного інтересів як прояв дуалізму в праві полягає в тому, що між публічним і приватним інтересами існує взаємозв' язок і взаємозалежність - без задоволення публічного інтересу неможливо реалізувати приватний інтерес і забезпечити цілісність, стабільність і нормальний поступ суспільства та держави в цілому. Оптимальне співвідношення публічного та приватного інтересів як у соціальній практиці, так і в правовому регулюванні $\epsilon$ необхідною умовою гармонійного розвитку суспільства, окремої особи, ефективності функціонування держави. Формами співвідношення приватного та публічного інтересів у праві є поєднання, гармонізація, компроміс, узгодження та ін. Встановлення рівноваги приватного та публічного інтересів у праві за будь-яких умов не може однозначно бути оптимальною формою, оскільки за певних обставин слід встановити пріоритет одного інтересу, й, отже, обмеження іншого [12, с. 159-160].

Сфера правового впливу норм цивільного законодавства обмежена виключно приватною сферою, в якій відносини учасників цивільних відносин засновані на юридичній рівності, вільному волевиявленні, майновій самостійності. Хоча й ст. 2 ЦК України передбачена можливість суб'єктів публічного права бути учасниками цивільних відносин [13], тим не менш цивільно-правове регулювання суспільних відносин спрямоване на задоволення інтересу приватного.

Екологічне право ж за своєю сутністю відноситься до публічно-приватних галузей права [9, c. 416], $з$ домінуванням публічно-правових засад. При цьому, публічність еколого-правової сфери характеризується поряд із безумовною соціальною значущістю, цінністю й загальністю екологічного інтересу ще й методологічною потребою підтримання балансу між двома групами суспільно значущих інтересів, умовно позначених як економічні й екологічні, з огляду на розумне їх поєднання [10, c. 93].

Наприклад, на необхідності враховувати екологічні інтереси у праві власності на природні ресурси наголошував В.С. Шахов, який вказував, що встановлена законодавчо можливість природних ресурсів тому чи іншому суб'єкту не тільки визначає їх подальше використання, тим самим обумовлюючи баланс екологічних інтересів суспільства, а i має соціальне значення для нинішнього та майбутнього поколінь людства, які бажають реалізації власних екологічних інтересів [14, c. 229].

Принципова необхідність дотримання балансу між публічними та приватними інтересами (а отже і гармонізація публічної та приватної власності) забезпечується й практикою міжнародних судових інституцій. Так, у рішенні ЄСПЛ від 23.09.1982 р. у справі «Спорронг і Льоннрот проти 
Швеції» (Case of Sporrong and Lonnroth v. Sweden) зазначається, що перше речення статті 1 Протоколу № 1 до Конвенції про захист прав і основоположних свобод містить гарантію права приватної власності. Це положення у загальних словах захищає людину та приватних юридичних осіб від втручання у мирне володіння своїм майном. Однак сучасні держави зобов'язані, керуючись інтересами суспільства, регулювати порядок використання приватного майна в багатьох аспектах. Право власності та використання власності завжди пов'язані з існуючими соціальними потребами та обов'язками [15].

Висновки та перспективи подальшого дослідження. Особливості змісту права власності щодо володіння, користування та розпорядження об'єктами тваринного світу грунтуються на екстраполяції норм двох галузей права, що обумовлює співвідношення еколого-правових та цивільноправових підстав виникнення, зміни та припинення права власності на тваринний світ. Такий міжгалузевий підхід до правового регулювання відносин приналежності на зазначений об'єкт охорони навколишнього природного середовища вимагає дотримання публічних та приватних інтересів, що, у свою чергу, може забезпечуватися імплементацією екологічного імперативу у приватне право. Проте, враховуючи комплексність питання права власності на тваринний світ в цілому, та проблему забезпечення публічно-приватних засад у сфері його приналежності зокрема, перспективним та самостійним напрямком дослідження стає з'ясування механізму реалізації та гарантії забезпечення публічних та приватних інтересів у фауністичному праві України.

\section{Джерела та література}

1. Каракаш I. I. Право власності на природні об’єкти та їх ресурси в Україні: монографія / I. I. Каракаш. - Одеса: Юрид. літ., 2017. - 438 с.

2. Кулинич П. Ф. Правові проблеми охорони і використання земель сільськогосподарського призначення в Україні: монографія / П. Ф. Кулинич. - Київ: Логос, 2011. - 688 с.

3. Про тваринний світ: Закон України від 13.12.2001 р. №2894-ІІІ // Голос України. - 2002. - 16 січ. (№9).

4. Шеховцов В. В. Правове регулювання права приватної власності на об'єкти тваринного світу в Україні: монографія / В. В. Шеховцов. - Харків: ФІНН, 2010. - 200 с.

5. Мичурин Е. А. Харьковская цивилистическая школа: право собственности: монография / Е. А. Мічурин; под ред. И. В. Спасибо-Фатеевой. - Харьков: Право, 2012. - С. 99-112.

6. Про охорону навколишнього природного середовища: Закон України від 25 черв. 1991 р. // Відомості Верховної Ради України. - 1991. - № 41. - Ст. 546.

7. Резолюція 1803 (XVII) Генеральної Асамблеї ООН «Невід’ємний суверенітет над природними ресурсами» (прийнята 14 грудня 1962 р. на 1194-му пленарному засіданні Генеральної Асамблеї OОН) [Електронний ресурс]. - Режим доступу: https://zakon.rada.gov.ua/laws/show/995_819.

8. Устименко В. А. Публічна власність : проблеми теорії і практики: монографія / В. А. Устименко. Чернігів: Десна Поліграф, 2014. - 308 с.

9. Анісімова Г. В. Теоретичні засади розвитку екологічного законодавства в контексті природноправової доктрини: монографія / Г. В. Анісімова. - Харків: Право, 2019. - 672 с.

10. Соколова А. К. Флористичне право України: проблеми формування та розвитку: монографія. Харків. Право, 2009. - 288 с.

11. Домашенко М. В., Рубаник В. С. Власність і право власності: Нариси з історії, філософії, теорії і практики регулювання відносин власності в Україні / М. В. Домашенко, В. С. Рубаник. - Харків: Факт, 2002. - 550 с.

12. Гуняк О. Я. Приватний і публічний інтереси у праві: теоретико-правове дослідження: дис. ... канд. юрид. наук: 12.00.01 / О. Я. Гуняк. - Івано-Франківськ, 2016. - 236 с.

13. Цивільний кодекс України від 16 січня 2003 року № 435-IV // Голос України. - 2003. - 12 березня. - № 45.

14. Шахов В. С. Екологічна складова інституту права власності на природні об'єкти / В. С. Шахов // Теоретичні та практичні аспекти реалізації екологічного, земельного, аграрного права в умовах сталого розвитку України: матеріали «круглого столу» (м. Харків, 2 груд. 2016 р.). - Харків: Право, 2016. - C. 312-319.

15. Справа «Спорронг і Льоннрот проти Швеції»: Рішення Європейського суду з прав людини від 23. 09. 1982 p. [Електронний ресурс]. - Режим доступу: https://zakon.rada.gov.ua/laws/show/ 980_098\#Text. 
Шеховцов В. Правовое обеспечение публичных и частных интересов в фаунистическом праве Украины в контексте права собственности на животный мир. В статье исследуются основные вопросы права собственности на животный мир и его объекты через призму публичной и частной собственности. Установлено, что животный мир является уникальным природным ресурсом, a видовые, физиологические и биологические особенности животных обуславливают междисциплинарный характер правовой регламентации общественных отношений в сфере принадлежности животного мира. Разграничение сфер влияния гражданского (частного) и экологического (публичного) права имеет важное как теоретическое, так и практическое значение для обеспечения реализации соответствующих интересов участников общественных отношений. На основании обобщения научной доктрины, автор поддерживает существующие наработки и обосновывает необходимость оптимального сбалансирования этих интересов, а в случае возникновения конфликта интересов - приоритетом наделять публичные интересы, которые направлены на рациональное использование объектов животного мира, сохранение популяций диких животных и мест их обитания в частности, и обеспечение благоприятной экологической обстановки в мире в целом. Непосредственное обращение к фаунистическому законодательству доказывает существование двойной юридической конструкции права собственности: с одной стороны, владельцем всего животного мира как объекта права собственности является Украинский народ как интегрирующая правовая категория, а с другой стороны, конкретные индивидуализированные объекты животного мира могут находиться и в государственной, коммунальной или частной собственности. Особенности содержания права собственности по владению, пользованию и распоряжению объектами животного мира основываются на экстраполяции норм двух отраслей права, что обусловливает соотношение эколого-правовых и гражданско-правовых оснований возникновения, изменения и прекращения права собственности на животный мир. Такой межотраслевой подход к правовому регулированию отношений собственности на указанный объект охраны окружающей природной среды требует соблюдения публичных и частных интересов, что, в свою очередь, может обеспечиваться имплементацией экологического императива в частное право.

Ключевые слова: право собственности на животный мир, публичная собственность, частная собственность, публично-частные принципы права собственности на животный мир, экологические интересы.

Shekhovtsov V. Legal Support of Public and Private Interests in the Law on Fauna of Ukraine: the Context of the Right to Ownership of Fauna. The article examines the main issues of ownership of the animal world and its objects through the lens of public and private property. The fauna is a unique natural resource, and the species, physiological, and biological characteristics of animals determine the interdisciplinary nature of the legal regulation of social relations in the sphere of belonging to the fauna. The distinction between the spheres of influence of civil (private) and environmental (public) law is important both theoretically and practically to ensure the realization of the respective interests of the participants in public relations. The author supports the existing scientific doctrines, generalizes them, justifies the need for optimal balancing of these interests, and argues that in case of conflict of interests, the priority is on the side of the public interests, which are aimed at the rational use of wildlife, the conservation of wildlife populations and their habitats in particular, and ensuring a favorable ecological environment in the world as a whole. Direct appeal to the faunal legislation proves the existence of a double legal construction of right to property: on the one hand, the owner of the whole fauna as an object of right to property is the Ukrainian people as an integrating legal category, and on the other hand, specific individualized objects of fauna can be in state, communal or private property. The peculiarities of the content of right to property which include the possession, using and disposing of the objects of the animal world are based on the extrapolation of the two branches of law, which determines the ratio of environmental and civil grounds for the emergence, change and termination of of right to property. Such a cross-sectoral approach to the legal regulation of property to the specified object of environmental protection requires the observance of public and private interests, which, can be ensured by the implementation of the environmental imperative in private law.

Key words: ownership of fauna, public property, private property, public-private principles of ownership of fauna, ecological interests. 